\title{
COMPARISON ON THE TOLERANCE AND ACCUMULATION OF HEXAVALENT CHROMIUM BY DIFFERENT CROPS UNDER HYDROPONIC CONDITIONS
}

\author{
SUN, Z. Q. - QIU, Y. H. - LI, S. W. - HAN, X. M. - LI, H. L.* \\ School of Water Conservancy and Environment, University of Jinan, Jinan 250022, China \\ *Corresponding author \\ e-mail: ujn_lihl@163.com \\ (Received $9^{\text {th }}$ Apr 2019; accepted $2^{\text {nd }}$ Jul 2019)
}

\begin{abstract}
Seedlings of six crops including wheat, radish, cucumber, Chinese cabbage, oilseed rape, and lettuce were treated with hexavalent chromium $(\mathrm{Cr}(\mathrm{VI}))$ in a hydroponic system. Root surface area, tissue biomass, the activities of superoxide dismutase (SOD) and peroxidase (POD), and chromium contents were determined to evaluate the tolerance and accumulation of $\mathrm{Cr}(\mathrm{VI})$ by these crops. The results showed that the biomass reduction of wheat was the lowest, and that of lettuce was the highest. Significant decrease in SOD activity was observed in $1 \mathrm{mg} / \mathrm{L} \mathrm{Cr}(\mathrm{VI})$ treatment for Chinese cabbage and radish. While significant activation effect on the POD was observed in $1 \mathrm{mg} / \mathrm{L}$ or $5 \mathrm{mg} / \mathrm{L} \mathrm{Cr}(\mathrm{VI})$ treatment for Chinese cabbage and oilseed rape. Moreover, the activities of the two antioxidant enzymes in cucumber leaves did not change significantly at the two levels of $\mathrm{Cr}(\mathrm{VI})$ concentrations. The transfer coefficient of Chinese cabbage was the highest, while that of lettuce was the lowest. In conclusion, Chinese cabbage has a certain tolerance to $\mathrm{Cr}(\mathrm{VI})$ and exhibits the highest accumulation of $\mathrm{Cr}$ in the edible parts. Therefore, when planting crops in low and medium Cr contaminated soil, concerns should be addressed on the food safety issues from leafy vegetables, especially Chinese cabbage.
\end{abstract}

Keywords: crop, chromium (VI), physiological and biochemical properties, accumulation

\section{Introduction}

Crops are one of the most important sources of human food, providing the essential energy and nutrients for the human body. There is increasing concern regarding the health risks arising from the absorption and accumulation of heavy metals by the edible parts of crops (Noli and Tsamos, 2016). Among all the heavy metals, chromium (Cr) is considered as a serious environmental contaminant for the biota (Kabata-Pendias, 2011). Consumption of contaminated foods is considered to be the most common pathway of human exposure to Cr compared to inhalation and dermal contact (Wang et al., 2011). $\mathrm{Cr}$ (III) and $\mathrm{Cr}(\mathrm{VI})$ are the two main forms of chromium, among which $\mathrm{Cr}(\mathrm{VI})$ has higher water solubility and thus higher bioavailability. Due to its high redox potential, $\mathrm{Cr}(\mathrm{VI})$ can interfere with photosynthesis and respiration processes, uptake of water and minerals, enzyme activity, and leads to damage on the membrane lipid and DNA, resulting in a severe decline in crop yield and quality (Singh et al., 2013). Mutagenic and carcinogenic to humans, $\mathrm{Cr}(\mathrm{VI})$ is identified as a class A carcinogen (Prado et al., 2016; Feng et al., 2004). Therefore, studying the biotoxicity of Cr(VI) is essential for the safe production of agricultural products and the protection of the environment and human health.

There are some differences on the stress response and accumulation of $\mathrm{Cr}$ by different crops due to the differences in external morphology, internal structure as well as physiological and biochemical mechanisms on the absorption of heavy metals. For example, Bashri et al. (2016) studied the physiological and biochemical characteristics 
of two Amaranthus species, in which they found the species with higher antioxidant defense system exhibited higher tolerance to $\mathrm{Cr}(\mathrm{VI})$ stress. It was reported that members of the Brassicaceae family can absorb and transfer high concentrations of $\mathrm{Cr}$ into the edible parts (Singh et al., 2013; Cervantes et al., 2001). Furthermore, difference in the physiological and biochemical response and accumulation of $\mathrm{Cr}$ by different cultivars of the same crop was also reported. For example, Guo et al. (2015) observed that the growth of Lumai 22 (Cr tolerant wheat cultivar) was less inhibited than Zhoumai 9 ( $\mathrm{Cr}$ sensitive wheat cultivar). Moreover, a greater proportion of $\mathrm{Cr}$ was accumulated in the roots and the cell walls of the aerial parts in Lumai 22 compared with those of Zhoumai 9. Gill et al. (2015) found the ultrastructural damage in leaf mesophyll and root tip cells was most pronounced in Zheda 622 cultivar among the four different cultivars of Brassica napus L. Plants have specific mechanisms to protect from oxidative damages, such as enzymatic antioxidants and non-enzymatic antioxidants, which scavenge the reactive oxygen species (ROS). Wang et al. (2012) studied the tolerance of three species of grasses to $\mathrm{Cr}(\mathrm{VI})$ stress, in which they found Medicago sativa was less tolerant to $\mathrm{Cr}$ compared with Trifolium repens and Festuca arundinacea, which is likely due to the reduced activities of peroxidase (POD) and superoxide dismutase (SOD) of Medicago sativa with the increase of chromium concentration. Most of the above researches focused on the comparison of different cultivars of the same crop under the $\mathrm{Cr}$ stress. There are still knowledge gaps with regard to the stress response and accumulation of Cr by different crops.

Therefore, in this study, two levels of $\mathrm{Cr}(\mathrm{VI})$ were used for hydroponic treatment to study the stress response and accumulation of $\mathrm{Cr}$ by six crops including wheat, radish, cucumber, Chinese cabbage, oilseed rape, and lettuce. It can provide theoretical support for the rational and safe cultivation of crops in low and medium Cr-contaminated soil.

\section{Materials and methods}

\section{Materials}

The seeds of six crops including wheat (Jimai 22), radish (Zheda Chang), cucumber (green cucumber), Chinese cabbage (Jiaoyan 5869), oilseed rape (Shanghai Qing), and lettuce (four seasons lettuce) were purchased from Shandong Academy of Agricultural Sciences (Jinan, China), Ma'anshan Qiutian Seed Industry (Nanjing, China), Nanjing Jinshengda Seed (Nanjing, China), Qingdao Jiaoyan Seedling (Qingdao, China), Nanjing Jinshengda Seed (Nanjing, China), and Nanjing Green Collar Seed Industry Co., Ltd (Nanjing, China), seperately.

\section{Hydroponic experiment}

The seeds were firstly sterilized with $10 \% \mathrm{H}_{2} \mathrm{O}_{2}$ for $20 \mathrm{~min}$, then washed thoroughly with distilled water. Subsequently, the seeds were germinated on filter paper saturated with deionized water and placed in the dark at $25^{\circ} \mathrm{C}$ for $24 \mathrm{~h}$. The germinated seeds were grown in plastic pots filled with quartz sand, which were placed in an artificial climate chamber with the daylight/night time of $14 / 10 \mathrm{~h}$, daylight/night temperature of $24 \pm 2{ }^{\circ} \mathrm{C} / 18 \pm 2{ }^{\circ} \mathrm{C}$, the light intensity of 25000 lux, and the relative humidity of $75 \%$. Wheat, radish, and cucumber were cultured for 2 weeks. Chinese cabbage, oilseed rape, and lettuce were grown to the stage of 4 leaves and 1 core. Then uniform seedlings were selected and transferred to glass containers with $400 \mathrm{~mL}$ of modified Hoagland nutrient 
solution aerated with an air pump (4 seedlings per container). The nutrient solution ( $\mathrm{pH}=6.0$ ) consists of $944 \mathrm{mg} / \mathrm{L} \mathrm{Ca}\left(\mathrm{NO}_{3}\right)_{2}, 490 \mathrm{mg} / \mathrm{L} \mathrm{MgSO}_{4}, 136 \mathrm{mg} / \mathrm{L} \mathrm{KH}_{2} \mathrm{PO}_{4}$, $510 \mathrm{mg} / \mathrm{L} \mathrm{KNO} \mathrm{KN}_{3}, 2.86 \mathrm{mg} / \mathrm{L} \mathrm{H}_{3} \mathrm{BO}_{3}, 1.81 \mathrm{mg} / \mathrm{L} \mathrm{MnCl}_{2}, 0.22 \mathrm{mg} / \mathrm{L} \mathrm{ZnSO} 4,0.09 \mathrm{mg} / \mathrm{L}$ $(\mathrm{NH} 4)_{6} \mathrm{Mo}_{7} \mathrm{O}_{24}, 0.08 \mathrm{mg} / \mathrm{L} \mathrm{CuSO}_{4}$, and $3.67 \mathrm{mg} / \mathrm{L} \mathrm{NaFe-EDTA}$. After 3 days of acclimatization, the crops were exposed to $0,1 \mathrm{mg} / \mathrm{L}$ and $5 \mathrm{mg} / \mathrm{L}$ of $\mathrm{Cr}(\mathrm{VI})\left(\mathrm{K}_{2} \mathrm{CrO}_{4}\right)$. Each treatment had three replicates. The nutrient solution was renewed every 3 days.

\section{Measurement of gas exchange parameters}

The photosynthetic gas exchange parameters of the crops, including photosynthetic rate, stomatal conductance, and transpiration rate, were measured using a portable photosynthesis instrument (LC pro-SD, ADC, England) after 15 days of treatment.

\section{Measurement of growth and morphological parameters}

Crops were harvested and separated into roots and the aerial parts after 15 days of exposure, then washed with deionized water and dried with filter paper to measure the fresh biomass. The aerial parts were placed in an oven at $105^{\circ} \mathrm{C}$ for $30 \mathrm{~min}$, then dried at $70{ }^{\circ} \mathrm{C}$. The dry biomass was weighed. The roots were first scanned using a root scanner (ScanMaker i800plus, Shanghai Zhongjing Technology Co., Ltd., China) to measure the surface area, then were dried to measure the dry biomass. The dried crop tissues were pulverized with a stainless steel pulverizer for later use.

\section{Determination of antioxidant enzyme activity}

Frozen leaves were homogenized in $6 \mathrm{~mL}$ pre-cooled potassium phosphate buffer $(50 \mathrm{mM}, \mathrm{pH}=7.8)$ containing $1 \%(\mathrm{w} / \mathrm{v})$ polyvinylpyrrolidone $(\mathrm{PVP})$ with a chilled mortar and pestle. The homogenate was centrifuged at $10,000 \mathrm{~g}$ for $15 \mathrm{~min}$ at $4{ }^{\circ} \mathrm{C}$ and the supernatant obtained was used for enzymes assay.

SOD (EC 1.15.1.1) activity was determined by the nitroblue tetrazolium (NBT) method (Gonzalez et al., 1998). The assay mixture contained $50 \mathrm{mM}$ phosphate buffer (pH 7.8), $130 \mathrm{mM}$ methionine, $750 \mu \mathrm{M}$ NBT, $100 \mu \mathrm{M}$ EDTA-Na2, and $20 \mu \mathrm{M}$ riboflavin. A total volume of $3.3 \mathrm{~mL}$ assay mixture was placed under a $4000 \mathrm{~lx}$ fluorescent lamp for 15-20 $\mathrm{min}$ and then determined using an ultraviolet visible spectrophotometer (UV-2550, Shimadzu, Japan) at $560 \mathrm{~nm}$. One unit of SOD activity is the amount of enzyme that is required to cause $50 \%$ inhibition in the reduction of NBT. POD (EC 1.11.1.7) activity was determined using the guaiacol method (Zhou and Leul, 1998). The reaction mixture was comprised of $50 \mathrm{mM}$ phosphate buffer $(\mathrm{pH}=7.8)$, $30 \% \mathrm{H}_{2} \mathrm{O}_{2}, 20 \mathrm{mM}$ guaiacol, and $100 \mu \mathrm{L}$ enzyme extract. Activities of POD were assayed by measuring the absorbance at $436 \mathrm{~nm}$ with $3 \mathrm{~mL}$ of the mixture. One unit of POD activity was defined as the amount of enzyme catalyzing the oxidation of $1 \mu \mathrm{mol}$ of guaiacol in $1 \mathrm{~min}$.

\section{Determination of Cr contents in the crop tissues}

For determination of $\mathrm{Cr}$ contents, a certain amount of the roots or the aerial parts was weighed into a digestion tube. Ten milliliter digestion solution consisting of $\mathrm{HNO}_{3}$ and $\mathrm{H}_{2} \mathrm{O}(1: 1, \mathrm{~V} / \mathrm{V})$ was added soaking overnight. A graphite digestion instrument (EE, USA) was used to digest the tissues for about $12 \mathrm{~h}$ at temperature of $105{ }^{\circ} \mathrm{C}$. Then $1 \mathrm{~mL}$ of $\mathrm{H}_{2} \mathrm{O}_{2}$ was added to the remaining digestion solution and continue to digest to obtain 
clear solution. The solution was made up to $50 \mathrm{~mL}$ using Milli-Q water. Chromium contents were measured by ICP-MS (iCAP Q, Thermo Fisher Scientific, America).

\section{Statistical analysis}

Bio-concentration factor (BCF) is the ratio of the concentration of heavy metals in the roots or the aerial parts of plants to that in soil or solution (Ding et al., 2016). The transfer factor (TF) is the percentage of $\mathrm{Cr}$ concentration in the aerial parts to that in the roots, indicating the ability of heavy metals to be translocated from the roots to the aerial parts (Ali et al., 2013). The tolerance index (TI) is the percentage of the biomass of crop at Cr stress to that of the control treatment (Wilkins, 1978).

Data processing and analysis were performed using Excel and SPSS 22. One-way ANOVA and the least squares deviation (LSD) test were used to compare the difference among different treatments. Statistical significance was accepted at $p<0.05$. The figures were graphed using Origin 2017 software. The data results were expressed as mean \pm standard error.

\section{Results}

\section{Effect of $\mathrm{Cr}(\mathrm{VI})$ on the growth traits of crops}

The fresh biomass and root area of the six crops showed a decreasing tendency with increasing $\mathrm{Cr}(\mathrm{VI})$ concentration (Table 1). For the treatments of $1 \mathrm{mg} / \mathrm{L}$ of $\mathrm{Cr}(\mathrm{VI})$, the root biomasses of wheat and Chinese cabbage were not significantly different from those of the control, while those of radish, cucumber, oilseed rape, and lettuce decreased significantly compared with those of the control, with reduction of $25 \%, 73 \%, 30 \%$, and $71 \%$, respectively. Treatments with $5 \mathrm{mg} / \mathrm{L}$ of $\mathrm{Cr}(\mathrm{VI})$ significantly reduced the root biomasses of all the six crops. The reduction in root biomass was the lowest for wheat (25\%), followed by radish (49\%), oilseed rape (59\%), Chinese cabbage $(68 \%)$, cucumber $(76 \%)$, and lettuce $(92 \%)$. The aerial biomasses of the six crops were reduced significantly under the two levels of $\mathrm{Cr}(\mathrm{VI})$ treatments. Similar to those of the roots, wheat showed the lowest reductions in the aerial biomass, which were $27 \%$ and $49 \%$, respectively. While lettuce presented the highest reduction, which were $82 \%$ and $94 \%$, respectively. Under $5 \mathrm{mg} / \mathrm{L}$ of $\mathrm{Cr}(\mathrm{VI})$ stress, the root and shoot TI of wheat were $75 \%$ and $51 \%$, respectively. While the root and shoot TI of lettuce were $7 \%$ and $6 \%$, respectively. The results indicated that wheat has stronger tolerance to $\mathrm{Cr}(\mathrm{VI})$ toxicity, while lettuce showed less tolerance compared with other crops.

Under the two levels of $\mathrm{Cr}(\mathrm{VI})$ stress, except for cucumber, the TI values for the aerial parts of the other five crops were all lower than those of the roots, indicating the biomasses of the aerial parts other than roots of these five crops are more sensitive to $\mathrm{Cr}(\mathrm{VI})$ toxicity and could be used as biomarkers.

\section{Effect of $\mathrm{Cr}(\mathrm{VI})$ on the photosynthetic properties of crops}

The photosynthetic rate and transpiration rate of the six crops responded differently under the two levels of $\mathrm{Cr}(\mathrm{VI})$ treatments (Table 2). Under $1 \mathrm{mg} / \mathrm{L}$ of $\mathrm{Cr}(\mathrm{VI})$ treatment, the stomatal conductance and transpiration rate of wheat, cucumber, and oilseed rape did not change significantly, while those of radish, Chinese cabbage, and lettuce decreased significantly. The stomatal conductance and transpiration rate of the six crops were significantly reduced under $5 \mathrm{mg} / \mathrm{L}$ of $\mathrm{Cr}(\mathrm{VI})$ treatment. The transpiration rates in 
the leaves of wheat, radish, cucumber, Chinese cabbage, oilseed rape, and lettuce were reduced by $63 \%, 79 \%, 56 \%, 60 \%, 71 \%$, and $87 \%$, respectively. The stress of $\mathrm{Cr}(\mathrm{VI})$ on the transpiration rate in the leaves of wheat, cucumber, and Chinese cabbage is relatively low, which may account for the insignificant change in the leaf water contents of these three crops under $\mathrm{Cr}(\mathrm{VI})$ treatment of $1 \mathrm{mg} / \mathrm{L}$ (Fig. 1). The photosynthetic rates of wheat, radish, and Chinese cabbage did not change significantly, while those of cucumber, oilseed rape, and lettuce were significantly reduced under $1 \mathrm{mg} / \mathrm{L}$ of $\mathrm{Cr}(\mathrm{VI})$ treatment. Under $5 \mathrm{mg} / \mathrm{L}$ of $\mathrm{Cr}(\mathrm{VI})$ treatment, the photosynthesis rates of wheat, radish, cucumber, Chinese cabbage, oilseed rape, and lettuce decreased significantly, with reductions of $51 \%, 61 \%, 55 \%, 41 \%, 79 \%$, and $80 \%$, respectively. The effects of $\mathrm{Cr}(\mathrm{VI})$ on the photosynthetic rates of wheat and Chinese cabbage are less than those of other crops, while are higher than those of oilseed rape and lettuce.

Table 1. Effect of $C r(V I)$ on the growth traits of crops

\begin{tabular}{c|c|c|c|c|c|c|c}
\hline Parameters & $\begin{array}{c}\text { Cr(VI) } \\
(\mathbf{m g} / \mathbf{L})\end{array}$ & Wheat & Radish & Cucumber & $\begin{array}{c}\text { Chinese } \\
\text { cabbage }\end{array}$ & $\begin{array}{c}\text { Oilseed } \\
\text { rape }\end{array}$ & Lettuce \\
\hline $\begin{array}{c}\text { Root biomass } \\
\text { (g per }\end{array}$ & 0 & $3.20 \pm 0.23 \mathrm{a}$ & $0.91 \pm 0.07 \mathrm{a}$ & $8.72 \pm 1.78 \mathrm{a}$ & $2.65 \pm 0.26 \mathrm{a}$ & $2.47 \pm 0.71 \mathrm{a}$ & $9.98 \pm 2.08 \mathrm{a}$ \\
container) & 5 & $2.41 \pm 0.10 \mathrm{~b}$ & $0.47 \pm 0.05 \mathrm{c}$ & $1.75 \pm 0.54 \mathrm{c}$ & $0.84 \pm 0.14 \mathrm{~b}$ & $1.02 \pm 0.19 \mathrm{c}$ & $0.78 \pm 0.07 \mathrm{c}$ \\
\hline Aerial & 0 & $4.98 \pm 0.39 \mathrm{a}$ & $15.1 \pm 0.37 \mathrm{a}$ & $19.6 \pm 1.45 \mathrm{a}$ & $23.7 \pm 1.33 \mathrm{a}$ & $22.4 \pm 2.04 \mathrm{a}$ & $63.0 \pm 9.2 \mathrm{a}$ \\
biomass (g & 1 & $3.62 \pm 0.16 \mathrm{~b}$ & $9.87 \pm 0.06 \mathrm{~b}$ & $8.61 \pm 1.55 \mathrm{~b}$ & $15.1 \pm 4.64 \mathrm{~b}$ & $12.7 \pm 1.94 \mathrm{~b}$ & $11.6 \pm 5.43 \mathrm{bc}$ \\
per container) & 5 & $2.56 \pm 0.03 \mathrm{c}$ & $5.16 \pm 0.05 \mathrm{c}$ & $5.70 \pm 0.34 \mathrm{c}$ & $5.53 \pm 0.87 \mathrm{c}$ & $6.63 \pm 0.59 \mathrm{c}$ & $3.84 \pm 0.44 \mathrm{~b}$ \\
\hline \multirow{2}{*}{ Root area } & 0 & $99.7 \pm 4.48 \mathrm{a}$ & $26.0 \pm 4.94 \mathrm{a}$ & $188 \pm 19.40 \mathrm{a}$ & $32.0 \pm 1.28 \mathrm{a}$ & $32.2 \pm 1.46 \mathrm{a}$ & $157 \pm 24.9 \mathrm{a}$ \\
$\left(\mathrm{cm}{ }^{2}\right)$ & 1 & $80.7 \pm 10.89 \mathrm{~b}$ & $14.6 \pm 0.44 \mathrm{bc}$ & $36.2 \pm 8.26 \mathrm{bc}$ & $29.8 \pm 4.70 \mathrm{ab}$ & $21.3 \pm 2.59 \mathrm{bc}$ & $38.3 \pm 2.93 \mathrm{bc}$ \\
\hline \multirow{2}{*}{ Root TI } & 5 & $53.4 \pm 2.12 \mathrm{c}$ & $12.1 \pm 1.65 \mathrm{c}$ & $35.9 \pm 6.67 \mathrm{c}$ & $18.8 \pm 1.12 \mathrm{c}$ & $17.3 \pm 0.68 \mathrm{c}$ & $18.8 \pm 0.89 \mathrm{c}$ \\
\hline \multirow{2}{*}{ Shoot TI } & 1 & 91 & 74 & 22 & 79 & 69 & 28 \\
& 5 & 75 & 51 & 20 & 40 & 41 & 7 \\
\hline \multirow{2}{*}{ Values } & 5 & 51 & 34 & 29 & 63 & 49 & 18 \\
\end{tabular}

Values are presented as means and standard error. Different letters indicate statistically significant difference between different treatments

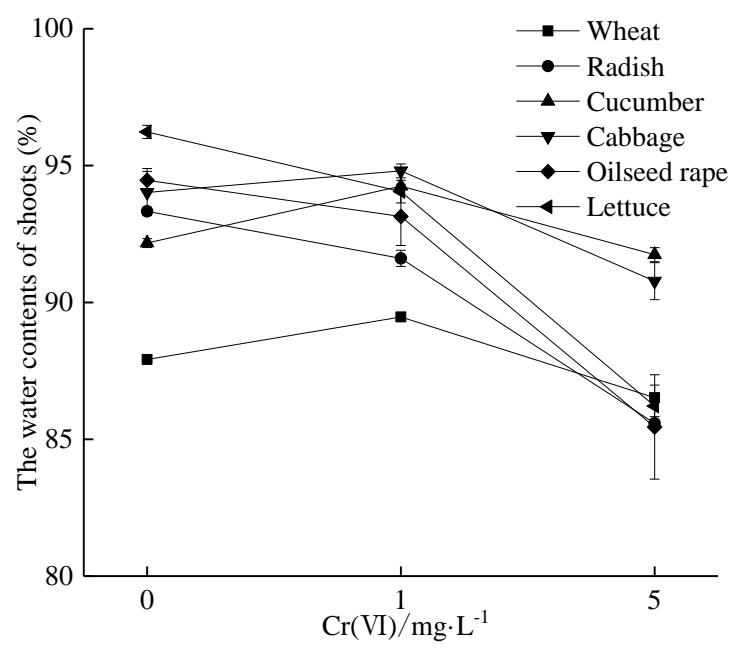

Figure 1. Effect of $C r(V I)$ on the water contents (\%) of the six crops. (Bars indicate standard error) 
Table 2. Effect of $\mathrm{Cr}(\mathrm{VI})$ on the photosynthetic parameters of crops

\begin{tabular}{c|c|c|c|c|c|c|c}
\hline Parameters & $\begin{array}{c}\text { Cr(VI) } \\
(\mathbf{m g} / \mathbf{L})\end{array}$ & Wheat & Radish & Cucumber & $\begin{array}{c}\text { Chinese } \\
\text { cabbage }\end{array}$ & $\begin{array}{c}\text { Oilseed } \\
\text { rape }\end{array}$ & Lettuce \\
\hline $\begin{array}{c}\text { Stomatal } \\
\text { conductance } \\
\left(\mathrm{mol} / \mathrm{m}^{2} / \mathrm{s}\right)\end{array}$ & 0 & $0.40 \pm 0.02 \mathrm{a}$ & $0.21 \pm 0.01 \mathrm{a}$ & $0.14 \pm 0.03 \mathrm{a}$ & $0.42 \pm 0.19 \mathrm{a}$ & $0.24 \pm 0.05 \mathrm{a}$ & $0.46 \pm 0.04 \mathrm{a}$ \\
\hline $\begin{array}{c}\text { Transpiration } \\
\text { rate }\end{array}$ & 5 & $0.11 \pm 0.01 \mathrm{c}$ & $0.03 \pm 0.01 \mathrm{c}$ & $0.05 \pm 0.04 \mathrm{~b}$ & $0.05 \pm 0.02 \mathrm{c}$ & $0.06 \pm 0.01 \mathrm{bc}$ & $0.02 \pm 0.00 \mathrm{c}$ \\
\hline $\begin{array}{c}\left.\text { mol } / \mathrm{m}^{2} / \mathrm{s}\right) \\
\text { Photosynthetic }\end{array}$ & 5 & $3.14 \pm 0.44 \mathrm{ab}$ & $2.09 \pm 0.43 \mathrm{a}$ & $1.22 \pm 0.18 \mathrm{ab}$ & $3.47 \pm 0.66 \mathrm{a}$ & $2.37 \pm 0.34 \mathrm{a}$ & $3.09 \pm 0.20 \mathrm{a}$ \\
$\begin{array}{c}\text { rate }(\mu \mathrm{mol} \\
\left.\mathrm{CO}_{2} / \mathrm{m}^{2} / \mathrm{s}\right)\end{array}$ & 1 & $11.6 \pm 2.19 \mathrm{ab}$ & $3.64 \pm 0.08 \mathrm{ab}$ & $1.98 \pm 0.16 \mathrm{bc}$ & $5.16 \pm 0.08 \mathrm{~b}$ & $4.87 \pm 0.26 \mathrm{ab}$ & $7.07 \pm 0.25 \mathrm{~b}$ \\
\hline
\end{tabular}

Values are presented as means and standard error. Different letters indicate statistically significant difference between different treatments

\section{Effects of $C r(V I)$ on the activities of antioxidant enzymes}

The effects of $\mathrm{Cr}(\mathrm{VI})$ on the SOD and POD activities of the six crops are shown in Figure 2.

As can be seen, $\mathrm{Cr}(\mathrm{VI})$ treatment of $5 \mathrm{mg} / \mathrm{L}$ significantly inhibited the SOD activity of all the crops except that of cucumber. Moreover, for Chinese cabbage and radish, significant decrease in SOD activity was observed at $1 \mathrm{mg} / \mathrm{L}$ of $\mathrm{Cr}(\mathrm{VI})$ treatment. Especially for radish, SOD activity was not detected at the two levels of $\mathrm{Cr}$ (VI) treatments. It is suggested that Chinese cabbage and radish are sensitive to the stress of $\mathrm{Cr}(\mathrm{VI})$. Similar to that of SOD, Cr(VI) treatment of $5 \mathrm{mg} / \mathrm{L}$ resulted in significant inhabitation on POD activity of all the crops except cucumber and oilseed rape. For Chinese cabbage and oilseed rape, significant activation effect on the POD was observed at $1 \mathrm{mg} / \mathrm{L}$ or $5 \mathrm{mg} / \mathrm{L}$ of $\mathrm{Cr}(\mathrm{VI})$ treatment. Interestingly, the SOD and POD activities of cucumber did not change significantly at the two levels of $\mathrm{Cr}(\mathrm{VI})$ treatments. This indicated that cucumber is not sensitive to the stress of $\mathrm{Cr}(\mathrm{VI})$.
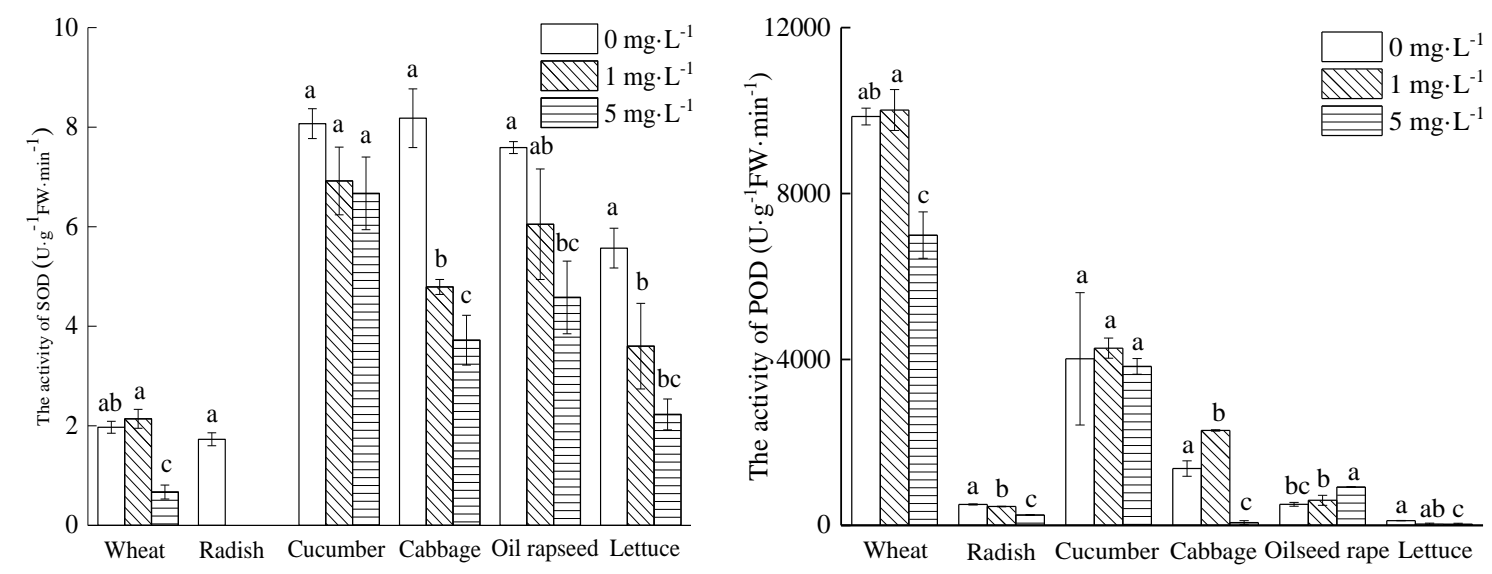

Figure 2. Effect of $\mathrm{Cr}(V)$ on the activities of antioxidant enzymes in crops. (Bars indicate standard error) 


\section{The accumulation of Cr by crops}

With the increase of $\mathrm{Cr}(\mathrm{VI})$ concentration in hydroponic solution, the $\mathrm{Cr}$ contents in the crop tissues increased significantly except the roots of cucumber and Chinese cabbage (Table 3). Under $\mathrm{Cr}(\mathrm{VI})$ treatment of $1 \mathrm{mg} / \mathrm{L}$, the $\mathrm{Cr}$ content in lettuce roots is the highest $(1024 \mu \mathrm{g} / \mathrm{g})$, followed by oilseed rape $(772 \mu \mathrm{g} / \mathrm{g})$, Chinese cabbage $(736 \mu \mathrm{g} / \mathrm{g})$, cucumber $(695 \mu \mathrm{g} / \mathrm{g})$, radish $(651 \mu \mathrm{g} / \mathrm{g})$, and wheat $(246 \mu \mathrm{g} / \mathrm{g})$. For $5 \mathrm{mg} / \mathrm{L}$ of $\mathrm{Cr}(\mathrm{VI})$ treatment, the $\mathrm{Cr}$ content in lettuce roots is also the highest $(2823 \mu \mathrm{g} / \mathrm{g})$, followed by radish $(1453 \mu \mathrm{g} / \mathrm{g})$, oilseed rape $(1161 \mu \mathrm{g} / \mathrm{g})$, Chinese cabbage $(876 \mu \mathrm{g} / \mathrm{g})$, cucumber $(700 \mu \mathrm{g} / \mathrm{g})$, and wheat $(427 \mu \mathrm{g} / \mathrm{g})$. The $\mathrm{Cr}$ contents in the aerial parts of the six crops were far below those of the roots. Under $\mathrm{Cr}(\mathrm{VI})$ treatment of $1 \mathrm{mg} / \mathrm{L}$, the $\mathrm{Cr}$ content in the aerial parts of Chinese cabbage is the highest $(35.9 \mu \mathrm{g} / \mathrm{g})$, followed by oilseed rape $(19.5 \mu \mathrm{g} / \mathrm{g})$, lettuce $(16.2 \mu \mathrm{g} / \mathrm{g})$, radish $(13.4 \mu \mathrm{g} / \mathrm{g})$, wheat $(13.2 \mu \mathrm{g} / \mathrm{g})$, and cucumber $(9.00 \mu \mathrm{g} / \mathrm{g})$. Under $\mathrm{Cr}(\mathrm{VI})$ treatment of $5 \mathrm{mg} / \mathrm{L}$, the $\mathrm{Cr}$ contents in the aerial parts of the six crops followed the same order.

Table 3. The uptake, accumulation, and translocation of Cr by crops

\begin{tabular}{c|c|c|c|c|c|c|c}
\hline & $\begin{array}{c}\text { Cr(VI) } \\
(\mathbf{m g} / \mathbf{L})\end{array}$ & Wheat & Radish & Cucumber & $\begin{array}{c}\text { Chinese } \\
\text { cabbage }\end{array}$ & $\begin{array}{c}\text { Oilseed } \\
\text { rape }\end{array}$ & Lettuce \\
\hline $\begin{array}{c}\text { Cr contents in } \\
\text { roots }(\mu \mathrm{g} / \mathrm{g} \\
\text { DW) }\end{array}$ & 1 & $246 \pm 22.3 \mathrm{~b}$ & $611 \pm 0.67 \mathrm{~b}$ & $695 \pm 38.9 \mathrm{ab}$ & $736 \pm 67.3 \mathrm{ab}$ & $772 \pm 20.9 \mathrm{~b}$ & $1024 \pm 105 \mathrm{~b}$ \\
\hline $\begin{array}{c}\text { Cr contents in } \\
\text { the aerial parts } \\
(\mu \mathrm{g} / \mathrm{g} \text { DW })\end{array}$ & 1 & $13.2 \pm 1.38 \mathrm{~b}$ & $13.4 \pm 1.79 \mathrm{~b}$ & $9.00 \pm 0.09 \mathrm{~b}$ & $35.9 \pm 5.55 \mathrm{~b}$ & $19.5 \pm 0.32 \mathrm{~b}$ & $16.2 \pm 2.96 \mathrm{~b}$ \\
\hline Aerial BCF & 1 & $13.0 \pm 1.10 \mathrm{a}$ & $13.4 \pm 1.79 \mathrm{a}$ & $9.00 \pm 0.09 \mathrm{a}$ & $35.9 \pm 5.55 \mathrm{ab}$ & $19.5 \pm 0.32 \mathrm{ab}$ & $16.2 \pm 2.96 \mathrm{a}$ \\
\hline Root BCF & 1 & $246 \pm 22.3 \mathrm{~b}$ & $603 \pm 7.75 \mathrm{a}$ & $784 \pm 91.2 \mathrm{a}$ & $736 \pm 67.3 \mathrm{a}$ & $862 \pm 90.9 \mathrm{a}$ & $737 \pm 89.8 \mathrm{a}$ \\
\hline & 5 & $111 \pm 25.5 \mathrm{a}$ & $290 \pm 1.84 \mathrm{~b}$ & $140 \pm 7.10 \mathrm{~b}$ & $210 \pm 36.1 \mathrm{~b}$ & $279 \pm 47.4 \mathrm{~b}$ & $565 \pm 52.1 \mathrm{~b}$ \\
\hline TF $(\%)$ & 1 & $5.12 \pm 0.57 \mathrm{~b}$ & $2.06 \pm 0.16 \mathrm{ab}$ & $1.16 \pm 0.11 \mathrm{~b}$ & $4.93 \pm 1.21 \mathrm{~b}$ & $2.48 \pm 0.26 \mathrm{~b}$ & $1.57 \pm 0.15 \mathrm{~b}$ \\
\hline
\end{tabular}

Values are presented as means and standard error. Different letters indicate statistically significant difference between different treatments

For the roots, the $\mathrm{BCF}$ values of the six crops decreased significantly with the increase of $\mathrm{Cr}(\mathrm{VI})$ treatment concentration. Under $\mathrm{Cr}(\mathrm{VI})$ treatment of $1 \mathrm{mg} / \mathrm{L}$, the $\mathrm{BCF}$ for wheat roots was significantly lower than those of other crops. Under $5 \mathrm{mg} / \mathrm{L}$ of $\mathrm{Cr}(\mathrm{VI})$ treatment, the root BCF of lettuce was the highest, followed by radish, oilseed rape, Chinese cabbage, cucumber, and wheat. For the aerial parts, the BCF of Chinese cabbage, oilseed rape, lettuce, and radish did not change significantly at the two levels of $\mathrm{Cr}(\mathrm{VI})$ treatments, while those of wheat and cucumber decreased significantly with the increase of $\mathrm{Cr}(\mathrm{VI})$ treatment concentration. The BCF of the aerial parts of Chinese cabbage is the highest, and that of cucumber is the lowest.

Except for radish, the TF of other crops increased significantly with the increase of $\mathrm{Cr}(\mathrm{VI})$ treatment concentration. Under $\mathrm{Cr}(\mathrm{VI})$ treatment of $1 \mathrm{mg} / \mathrm{L}$, the $\mathrm{TF}$ values of the six crops ranged from 1.16 to 5.12, following the order of wheat $>$ Chinese cabbage $>$ oilseed rape $>$ radish $>$ lettuce $>$ cucumber. Under $\mathrm{Cr}(\mathrm{VI})$ treatment of $5 \mathrm{mg} / \mathrm{L}$, the $\mathrm{TF}$ values of the six crops ranged from 2.92 to 18.6. Different from that of $1 \mathrm{mg} / \mathrm{L}$ 
treatment, the order is Chinese cabbage $>$ wheat $>$ oilseed rape $>$ cucumber $>$ radish $>$ lettuce.

\section{Discussion}

It has been demonstrated that $\mathrm{Cr}$ could inhibit the growth of plant, cause chlorosis in newly budded leaves and the decrease in root surface area. These indicators have been used to assess the responses of crops to the Cr stress (Bashri et al., 2016; Anjum et al., 2017; Liu et al., 2008; Pandey et al., 2005; Tiwari et al., 2009). In the present study, the biomasses of crop tissues decreased with the increase of $\mathrm{Cr}(\mathrm{VI})$ concentration in the nutrient solution (Table 1). The results are consistent with those of wheat seedlings exposed to $\mathrm{Cr}(\mathrm{VI})$ (Guo et al., 2015). All the six crops were stressed by $1 \mathrm{mg} / \mathrm{L}$ of $\mathrm{Cr}(\mathrm{VI})$, and the aerial parts of the six crops were more sensitive to $\mathrm{Cr}$ stress than the roots except for cucumber (Table 1). This may be due to the reduced root activity, which inhibits the transport of nutrients from roots to the aerial parts. The growth parameters of the six crops were significantly reduced because the crops could not acquire abundant nutrients to maintain normal physiological activity (Ali et al., 2013). The TI can be used to indicate the tolerance of crops to heavy metals, the greater the value, the stronger the tolerance of plants to heavy metals (Liu and Wang, 2002). In the present study, the growth parameters and the TI values indicated that wheat exhibited strong tolerance to $\mathrm{Cr}(\mathrm{VI})$ among the six crops, while lettuce was relatively less tolerant to $\mathrm{Cr}(\mathrm{VI})$.

The main parameters affecting crop photosynthesis and transpiration include stomatal conductance, transpiration rate, and photosynthetic rate. In this study, as the $\mathrm{Cr}(\mathrm{VI})$ treatment level increased, the stomatal conductance, transpiration rate, and photosynthetic rate of the six crops showed a decreasing tendency. The increase of chlorophyllase activity in crops resulted in the decomposition of chlorophyll under the stress of heavy metals (Hegedus and Erdei, 2001), which led to lower capacity for lightharvesting, thus the decrease in photosynthetic rate. On the other hand, the decrease of the photosynthetic rate under $\mathrm{Cr}(\mathrm{VI})$ stress may be attributed to the interference of $\mathrm{Cr}$ on nutrient absorption, respiration rate, and cell membrane permeability. In addition, $\mathrm{Cr}(\mathrm{VI})$ can induce chloroplast ultrastructural abnormalities, such as the alteration of thylakoid (Luisa Brito et al., 2009). The treatment of $5 \mathrm{mg} / \mathrm{L} \mathrm{Cr}(\mathrm{VI})$ significantly reduced the stomatal conductance of the crop leaves. This can be explained by the damage to the stomatal guard cells of crop leaves caused by the high oxidation potential of Cr(VI) (Hayat et al., 2012). Former study has found that $\mathrm{Cr}$ can reduce the tracheary diameter of bean plants, thereby reducing the longitudinal movement of water (Barceló and Poschenrieder, 1990), which may bring about the reduced transpiration rate of the crops. Similar results have also been reported by Gill et al. (2015), Liu et al. (2008), and Ali et al. (2011), in which they found that high concentrations of $\mathrm{Cr}$ can reduce the net photosynthetic rate, stomatal conductance, and transpiration rate of oilseed rape, Amaranthus viridis $L$ and barley. Heavy metal stress results in severe dehydration of plant shoots by interfering with the water transport from roots to shoots. In general, heavy metals can affect water contents through water absorption, water transformation of plastids and protoplasts, and stomatal function (Poschenrieder and Barceló, 1999). In this study, under the stress of $5 \mathrm{mg} / \mathrm{L}$ of $\mathrm{Cr}(\mathrm{VI})$, the water contents of wheat and cucumber did not change significantly, while those of radish, Chinese cabbage, oilseed rape, and lettuce decreased significantly. 
Subjected to $\mathrm{Cr}$ stress, crops are stimulated to produce reactive oxygen species (ROS), such as $\mathrm{H}_{2} \mathrm{O}_{2}, \mathrm{OH}^{-}, \mathrm{O}^{2-}$, which bring about oxidative damage to biomolecules such as lipids, proteins, and nucleic acids. Therefore, crops control the production of peroxidative radicals by developing a complex enzymatic antioxidant system to prevent plants from being oxidatively damaged (Ashraf et al., 2015). This defense mechanism includes various antioxidant enzymes such as SOD, catalase (CAT), and POD. Crop cells increase the activity of antioxidant enzymes and eliminate excess ROS to maintain ROS balance (Gill and Tuteja, 2010). The differences in antioxidant defense mechanisms induced by heavy metals depend on the species of heavy metal and crops (Hayat et al., 2012). SOD and POD are vital enzymes in crop antioxidant defense mechanisms. SOD is the most critical substance accounting for plant stress tolerance, providing a first line of defense to reduce the toxic effects caused by elevated levels of ROS. In general, the activities of antioxidant enzymes will be promoted under low concentration of heavy metal exposure while be inhibited under high concentrations of heavy metal exposure. Huang et al. (2011) showed that $10^{-6} \mathrm{~mol} / \mathrm{L}$ of $\mathrm{Cr}(\mathrm{VI})$ stress had no significant effect on SOD and POD activities in maize, while $10^{-5} \mathrm{~mol} / \mathrm{L}$ of $\mathrm{Cr}(\mathrm{VI})$ stress showed significant decreases in SOD and POD activities. In this study, under the stress of $\mathrm{Cr}(\mathrm{VI})$, the antioxidant enzyme activities of different crops were very different. The SOD and POD activities of wheat, cucumber, and oilseed rape as well as the POD activity of lettuce did not change significantly when treated with $1 \mathrm{mg} / \mathrm{L}$ of $\mathrm{Cr}(\mathrm{VI})$. The activities of SOD and POD in the leaves of radish and the activity of SOD in the leaves of Chinese cabbage and lettuce significantly decreased, while the activity of POD in the leaves of Chinese cabbage significantly increased. It showed that under $1 \mathrm{mg} / \mathrm{L}$ of $\mathrm{Cr}(\mathrm{VI})$ stress, wheat was tolerant to the Cr stress, while lettuce presented its sensitivity to the $\mathrm{Cr}$ stress. The increase of antioxidant enzyme activity may be attributed to the blockage of electron transport chains in mitochondria induced by $\mathrm{Cr}(\mathrm{VI})$, which directly affects the production of superoxide radicals. With the increase of $\mathrm{Cr}$ concentration, the enzyme activity decreases, which is due to the inhibition of $\mathrm{Cr}(\mathrm{VI})$ to the enzyme system (Hayat et al., 2012). Also, Huang et al. (2011) found that the dramatic changes in antioxidant enzyme activity may be related to the expression of isoenzymes during the transformation of nutritional mode.

The six crops showed considerable differences in the absorption, translocation, and accumulation of Cr. Wang et al. (2012) have found different oil crops showed different tolerance and accumulation of $\mathrm{Cr}$. In this study, $\mathrm{Cr}$ was mainly retained in the roots of the six crops, ranging from $2823 \mu \mathrm{g} / \mathrm{g}$ (lettuce) to $426.5 \mu \mathrm{g} / \mathrm{g}$ (wheat). However, due to the difference in the translocation of $\mathrm{Cr}$ by different crops, the TF of Chinese cabbage $(18.6 \%)$ was the highest, which resulted in the highest content of $\mathrm{Cr}(208.8 \mu \mathrm{g} / \mathrm{g})$ in the aerial parts of Chinese cabbage. The $\mathrm{Cr}$ contents in the aerial parts of oilseed rape and lettuce are significantly higher than those of the other three crops. It has been found that transpiration plays a vital role in the translocation of heavy metals by crops ( $\mathrm{Ji}$ et al., 2017). In this study, there is a significant positive correlation between the $\mathrm{TF}$ of $\mathrm{Cr}$ and the transpiration rate of the six crops under $\mathrm{Cr}(\mathrm{VI})$ treatment of $1 \mathrm{mg} / \mathrm{L}\left(\mathrm{R}^{2}=0.75\right)$, which was not observed under $\mathrm{Cr}(\mathrm{VI})$ treatment of $5 \mathrm{mg} / \mathrm{L}$ because of the higher toxic effect of $\mathrm{Cr}(\mathrm{VI})$ at this level.

Based on the above analysis, it can be found that wheat is more tolerant to $\mathrm{Cr}(\mathrm{VI})$ and has a weaker accumulation ability for $\mathrm{Cr}$, while lettuce is more sensitive to $\mathrm{Cr}(\mathrm{VI})$ and has a stronger ability to accumulate $\mathrm{Cr}$. Therefore, lettuce will bring more risks than wheat when planted in low and medium concentration $\mathrm{Cr}(\mathrm{VI})$-contaminated soils. This 
study is limited to the sensitivity and accumulation of $\mathrm{Cr}$ (VI) by six crops under hydroponic conditions. The treatment level of $5 \mathrm{mg} / \mathrm{L} \mathrm{Cr}(\mathrm{VI})$ may be too high, which resulted in excessive toxicity and high $\mathrm{Cr}$ contents in crops. Although the results can reflect the tolerance of crops to $\mathrm{Cr}(\mathrm{VI})$, the tolerance, the translocation and accumulation of $\mathrm{Cr}$ by these six crops in soil systems remain to be further studied.

\section{Conclusions}

Under $\mathrm{Cr}(\mathrm{VI})$ stress conditions, the growth traits and photosynthetic characteristics of the six crops were more inhibited with increasing treatment concentration. Among them, wheat showed the strongest tolerance to $\mathrm{Cr}(\mathrm{VI})$, with the lowest accumulation of $\mathrm{Cr}$ in the shoots. Lettuce presented to be the most sensitive vegetables, with most $\mathrm{Cr}$ accumulated in the roots. Chinese cabbage had a certain tolerance to $\mathrm{Cr}(\mathrm{VI})$ and showed the highest accumulation of $\mathrm{Cr}$ in the edible parts, which may pose a threat to the safety of agricultural products if planted in $\mathrm{Cr}$ contaminated soils. In this study, the results on the tolerance and accumulation of $\mathrm{Cr}$ were based on the hydroponic conditions, the accumulation of $\mathrm{Cr}$ in soil systems by these crops should be further studied in the future.

Acknowledgements. This research was funded by National Key Research and Development Program of China, grant number 2016YFD0800407. The authors would like to thank Prof. Yibing Ma for his suggestions on how to improve the manuscript.

\section{REFERENCES}

[1] Ali, B., Wang, B., Ali, S., Ghani, M. A., Hayat, M. T., Yang, C., Xu, L., Zhou, W. J. (2013): 5-aminolevulinic acid ameliorates the growth, photosynthetic gas exchange capacity, and ultrastructural changes under cadmium stress in Brassica napus L. - Journal of Plant Growth Regulation 32: 604-614.

[2] Ali, S., Zeng, F., Qiu, L., Zhang, G. (2011): The effect of chromium and aluminum on growth, root morphology, photosynthetic parameters and transpiration of the two barley cultivars. - Biologia Plantarum 55: 291-296.

[3] Ali, S., Farooq, M. A., Yasmeen, T., Hussain, S., Arif, M. S., Abbas, F., Bharwana, S. A., Zhang, G. (2013): The influence of silicon on barley growth, photosynthesis and ultrastructure under chromium stress. - Ecotoxicology and Environmental Safety 89: 66-72.

[4] Anjum, S. A., Ashraf, U., Khan, I., Tanveer, M., Shahid, M., Shakoor, A., Wang, L. (2017): Phyto-toxicity of chromium in maize: oxidative damage, osmolyte accumulation, anti-oxidative defense and chromium uptake. - Pedosphere 27: 262-273.

[5] Ashraf, U., Kanu, A. S., Mo, Z., Hussain, S., Anjum, S. A., Khan, I., Abbas, R. N., Tang, $X$. (2015): Lead toxicity in rice: effects, mechanisms, and mitigation strategies - a mini review. - Environmental Science and Pollution Research 22: 18318-18332.

[6] Barceló, J., Poschenrieder, C. (1990): Plant water relations as affected by heavy metal stress: a review. - Journal of Plant Nutrition 13: 1-37.

[7] Bashri, G., Parihar, P., Singh, R., Singh, S., Singh, V. P., Prasad, S. M. (2016): Physiological and biochemical characterization of two Amaranthus species under $\mathrm{Cr}(\mathrm{VI})$ stress differing in $\mathrm{Cr}(\mathrm{VI})$ tolerance. - Plant Physiology and Biochemistry 108: 12-23.

[8] Cervantes, C., Campos-Garcia, J., Devars, S., Gutiérrez-Corona, F., Loza-Tavera, H., Torres-Guzmán, J. C., Moreno-Sánchez, R. (2001): Interactions of chromium with microorganisms and plants. - FEMS Microbiology Reviews 25: 335-347. 
[9] Ding, H., Wang, G., Lou, L., Lv, J. (2016): Physiological responses and tolerance of kenaf (Hibiscus cannabinus L.) exposed to chromium. - Ecotoxicology and Environmental Safety 133: 509-518.

[10] Feng, X. H., Yi, S., Sridhar, B. B. M., David, L. M. (2004): Distribution, transformation and bioavailability of trivalent and hexavalent chromium in contaminated soil. - Plant and Soil 265: 243-252.

[11] Gill, R. A., Zang, L., Ali, B., Farooq, M. A., Cui, P., Yang, S., Ali, S., Zhou, W. (2015): Chromium-induced physio-chemical and ultrastructural changes in four cultivars of Brassica napus L. - Chemosphere 120: 154-164.

[12] Gill, S. S., Tuteja, N. (2010): Reactive oxygen species and antioxidant machinery in abiotic stress tolerance in crop plants. - Plant Physiology and Biochemistry 48: 909-930.

[13] Gonzalez, A., Steffen, K. L., Lynch, J. P. (1998): Light and excess manganese. Implications for oxidative stress in common bean. - Plant Physiology 118: 493-504.

[14] Guo, H. Y., Zhang, H., Tian, Z., Wang, Q., Sun, J., Dai, Y. (2015): Genotypic differences of chromium absorption and tolerance mechanism to chromium stress in wheat seedlings. - Journal of Triticeae Crops 35: 1386-1394 (in Chinese).

[15] Hayat, S., Irfan, M., Wani, A. S., Tripathi, B. N., Ahmad, A. (2012): Physiological changes induced by chromium stress in plants: an overview. - Protoplasma 249: 599-611.

[16] Hegedus, A., Erdei, S. G. (2001): Comparative studies of $\mathrm{H}_{2} \mathrm{O}_{2}$ detoxifying enzymes in green and greening barley seedlings under cadmium stress. - Plant Science 160: 10851093.

[17] Huang, H., Gao, X., Wang, J. (2011): The influence of $\mathrm{Cr}(\mathrm{VI})$ to the growth and antioxidant system of seedling of Zea mays L. - Journal of Agro-Environment Science 30: 633-638 (in Chinese).

[18] Ji, Y., Wan, Y., Wang, Q., Zhang, Y., Li, H. (2017): Effects of root characteristics and transpiration on cadmium uptake by cucumber seedlings under varied iron levels. - Acta Scientiae Circumstantiae 37: 1939-1946 (in Chinese).

[19] Kabata-Pendias, A. (2011): Trace Elements in Soils and Plants. 4th Ed. - CRC Press, Boca Raton, FL.

[20] Liu, D., Zou, J., Wang, M., Jiang, W. (2008): Hexavalent chromium uptake and its effects on mineral uptake, antioxidant defence system and photosynthesis in Amaranthus viridis L. - Bioresource Technology 99: 2628-2636.

[21] Liu, X., Wang, Q. (2002): Research on lead uptake and tolerance in six plants. - Acta Phytoecologica Sinica 26: 533-537 (in Chinese).

[22] Luisa Brito, P., Jurandi Gonçalves de, O., Ricardo, A. A., Douglas Rodrigues, R., Marcelo Gomes da, S., Angela, P. V. (2009): Ecophysiological responses of water hyacinth exposed to $\mathrm{Cr}^{3+}$ and $\mathrm{Cr}^{6+}$. - Environmental and Experimental Botany 65: 403409.

[23] Noli, F., Tsamos, P. (2016): Concentration of heavy metals and trace elements in soils, waters and vegetables and assessment of health risk in the vicinity of a lignite-fired power plant. - Science of the Total Environment 563-564: 377-385.

[24] Pandey, V., Dixit, V., Shyam, R. (2005): Antioxidative responses in relation to growth of mustard (Brassica juncea cv. Pusa Jaikisan) plants exposed to hexavalent chromium. Chemosphere 61: 40-47.

[25] Poschenrieder, C., Barceló, J. (1999): Water Relations in Heavy Metal Stressed Plants. In: Prasad, M. N. V. (ed.) Heavy Metal Stress in Plants. 2nd Ed., Springer, Berlin.

[26] Prado, C., Ponce, S. C., Pagano, E., Prado, F. E., Rosa, M. (2016): Differential physiological responses of two Salvinia species to hexavalent chromium at a glance. Aquatic Toxicology 175: 213-221.

[27] Singh, H. P., Mahajan, P., Kaur, S., Batish, D. R., Kohli, R. K. (2013): Chromium toxicity and tolerance in plants. - Environmental Chemistry Letters 11: 229-254.

[28] Tiwari, K. K., Dwivedi, S., Singh, N. K., Rai, U. N., Tripathi, R. D. (2009): Chromium (VI) induced phytotoxicity and oxidative stress in pea (Pisum sativum L.): biochemical 
changes and translocation of essential nutrients. - Journal of Environmental Biology 30: 389.

[29] Wang, A., Huang, S., Zhong, G., Xu, G., Liu, Z., Shen, X. (2012): Effect of Cr(VI) stress on growth of three herbaceous plants and their Cr uptake. - Environment Science 33: 2028-2037 (in Chinese).

[30] Wang, S., Lu, J. Y., Li, Y. X., Qi, J., Ye, Q. F. (2012): Chromium and lead tolerance and accumulation in several oil crops. - Journal of Agro-Environment Science 31: 1310-1316 (in Chinese).

[31] Wang, Z. X., Chen, J. Q., Chai, L. Y., Yang, Z. H., Huang, S. H., Zheng, Y. (2011): Environmental impact and site-specific human health risks of chromium in the vicinity of a ferro-alloy manufactory, China. - Journal of Hazardous Materials 190: 980-985.

[32] Wilkins, D. A. (1978): The measurement of tolerance to edaphic factors by means of root growth. - New Phytologist 80: 623-633.

[33] Zhou, W., Leul, M. (1998): Uniconazole-induced alleviation of freezing injury in relation to changes in hormonal balance, enzyme activities and lipid peroxidation in winter rape. Plant Growth Regulation 26: 41-47. 